Research Article

\title{
Histomorphological Study of Leprosy with Clinical Correlation in Kumaon Region
}

\author{
Neha Yadav', Binay Kumar², Usha Joshi ${ }^{3}$, Mukesh Kumar ${ }^{4}$, Saurabh Agarwal $^{5}$ \\ ${ }^{1}$ PG Student, Department of Pathology,Government medical college, Haldwani, Uttarakhand \\ ${ }^{2}$ Professor, Department of Pathology, Government medical college, Haldwani, Uttarakhand \\ ${ }^{3}$ Associate Professor, Department of Pathology, Government medical college,Haldwani, Uttarakhand \\ ${ }^{4}$ Associate Professor, Department of microbiology,Narayan medical college, Jamuhar,Bihar \\ ${ }^{5}$ Professor, Department of Skin \& V.D, Government medical college, Haldwani, Uttarakhand
}

\begin{abstract}
:
Background:

Leprosy is a leading cause of permanent physical disability. Approx $60 \%$ of global burden of leprosy is represented by India. Histopathological examination is still considered gold standard for accurate categorization of leprosy so that timely treatment can be started.

Objectives: To categorize and correlate types of leprosy clinically and histomorphologically in Kumaon region.

Methods: The present cross-sectional study of 62 cases was conducted in the Department of Pathology \& Skin and V.D in a tertiary care centre of Kumaon region from August 2016 to April 2018. The cases were clinically examined and categorized according to Ridley-Jopling classification. Skin Biopsy and Slit-Skin Smear (SSS) were taken for accurate histomorphogical categorization of leprosy and assessment of bacterial index, followed by clinico-histomorphological correlation. Statistical analysis was done in term of chi-square test. Kappa test was used as agreement test for clinical versus histological classification of different type of leprosy.

Results: A total of 62 clinically diagnosed leprosy cases evaluated histopathologically. Clinically, lepromatous leprosy (LL) was the most common type of leprosy (38.70\%), followed by borderline tuberculoid (30.64\%). On histopathological examination, indeterminate leprosy (IL) (21 cases; 33.90\%) was the most common followed by lepromatous leprosy (16 cases; $\mathbf{2 5 . 8 0 \%}$ ). Overall clinico-histopathological correlation was seen in 36 cases $(58.06 \%)$ with maximum correlation seen in indeterminate leprosy $(\mathbf{1 0 0 \%})$ and tuberculoid leprosy (TT) $(\mathbf{1 0 0 \%})$.

Conclusion: This study concludes that correlation of clinical and histopathological features along with bacterial index is more useful for accurate typing of leprosy than considering any of the single parameter alone so that early and appropriate treatment could be started.
\end{abstract}

Keywords: Bacterial index, clinically, histopathological, leprosy, Ridley-Jopling classification.

\section{Introduction}

The leprosy is endemic in many countries with approximately 211,000 new cases reported every year. In India the overall prevalence of leprosy has declined from $5.27 / 10000$ in year 2000 to $0.66 / 10000$ in year $2016 .^{[1]}$

In 1966, Ridley and Jopling(R-J) created a classification which is based on clinical, bacteriological, histopathological and immunological features. ${ }^{[2]}$ It is widely accepted by histopathologists and leprologists as it is precise and takes into account the progression and regression of disease under treatment.

The present study aimed to evaluate the role of histopathological findings and bacteriological index in exact typing of leprosy with clinical correlation in Kumaon region

\section{Body Text}

\section{A. Methods:}

This cross sectional study of two years (September 2016 August 2018) duration included 62, untreated and clinically suspected cases of leprosy, attending to the department of
Skin and V.D. \& Department of Pathology in a tertiary care centre of Kumaon region.

\section{B. Procedure:}

After obtaining formal permission from the institutional Ethical committee, skin biopsies with 4-6mm size punch needle were taken from the most representative lesion and were stained with Haematoxylin \& Eosin $(\mathrm{H} \& \mathrm{E})$ stain for morphological analyses and with Wade-Fite stain for assessment of bacterial load. In the same sitting, slit skin smears from the ear lobules were also made and stained with Wade- Fite stain for assessment of bacterial index. The diagnosis and categorization of leprosy was done histopathologically according to the R-J criteria and the clinico-histopathological correlation was done.

C. Statistical Analysis: It was done in term of chi-square test. Kappa test was used as agreement test for clinical versus histological classification of different type of leprosy. Descriptive analysis was done in the form of percentage or proportions. $\mathrm{P}$ value $<0.05$ was considered significant. The 


\section{Neha Yadav et.al Histomorphological Study of Leprosy with Clinical Correlation in Kumaon Region}

data were analysed using Microsoft Excel 2010 data analysis tool and SPSS (Statistical Programme for Social Science) version 16.0 for windows.

\section{Results}

The present study was conducted on 62 clinically suspected cases of leprosy patients which included 38(61.3\%) males and $24(38.7 \%)$ females with male to female ratio (M: F) of 1.58: 1. Majority of the cases (16 cases; $25.8 \%$ ) belonged to the age group of $11-20$ years. 42 cases $(67.74 \%)$ presented with erythematous lesions and 20 cases $(32.25 \%)$ presented with hypopigmented lesions. Hypoesthesia was seen in 32 cases $(51.61 \%)$, nerve thickening was seen in 28 cases $(45.17 \%)$ and the ulnar nerve was the most commonly involved nerve (16 cases; $25.80 \%$ ).

Clinically, majority of cases belonged to LL (24 cases; $38.70 \%$ ) followed by BT (19 cases; $30.64 \%$ ) and the least number of cases belonged to TT ( 2 cases; $3.22 \%$ ) [Figure1].

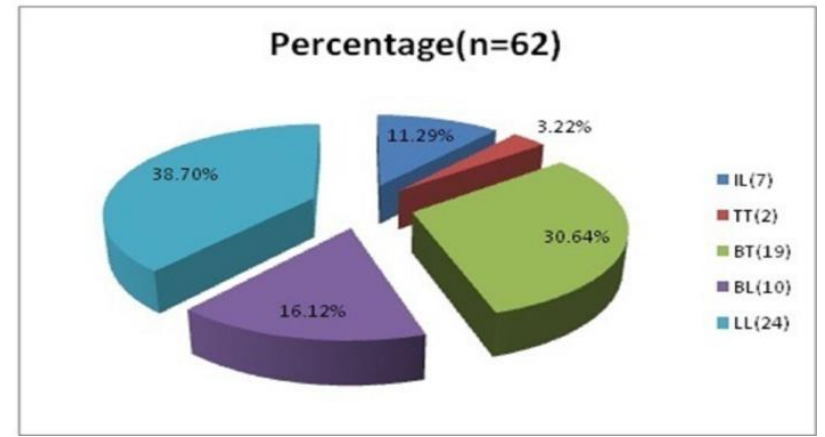

Figure 1: Shows clinical spectrum of various types of leprosy.

Histopathologically, IL (21 cases; 33.90\%) constituted the major group followed by LL (16 cases; 25.80\%) and borderline lepromatous (BL) leprosy (11cases; 17.70\%). The least common was borderline borderline (BB) (1 case; $1.60 \%$ ) leprosy [Figure2].

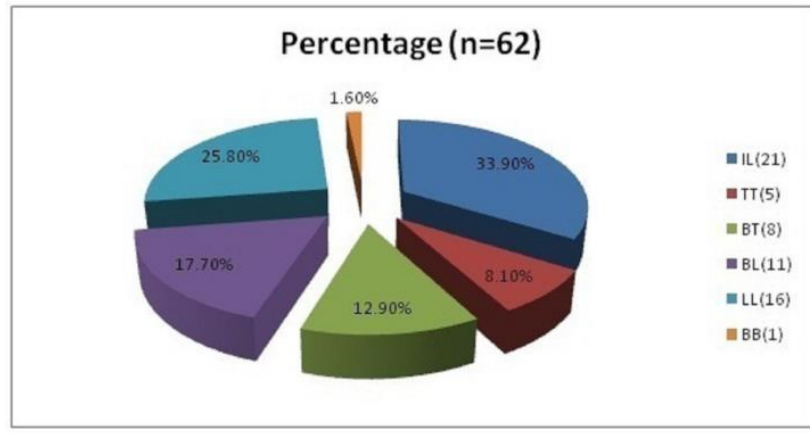

Figure 2: Shows histopathological spectrum of various types of leprosy.

62 biopsies were studied for the various epidermal and dermal changes according to Ridley-Jopling classification as summerised in Table [1a and 1b].

Table 1(a, b): Summary of Histopathological findings observed in various types of Leprosy:

Table (1a): Epidermal changes:

\begin{tabular}{|c|c|c|c|c|c|c|c|}
\hline $\begin{array}{c}\text { Epidermal } \\
\text { changes }\end{array}$ & IL(21) & TT(5) & BT(8) & BL(11) & LL(16) & BB(1) & Percentage(n=62) \\
\hline Unremarkable & $19(90.47 \%)$ & $4(80 \%)$ & $7(87.50 \%)$ & $11(100 \%)$ & $16(100 \%)$ & $1(100 \%)$ & $58(93.54 \%)$ \\
\hline Atrophy & $2(9.52 \%)$ & $0(0 \%)$ & $0(0 \%)$ & $0(0 \%)$ & $0(0 \%)$ & $0(0 \%)$ & $2(3.22 \%)$ \\
\hline Erosion & $0(0 \%)$ & $1(20 \%)$ & $1(12.5 \%)$ & $0(0 \%)$ & $0(0 \%)$ & $0(0 \%)$ & $2(1.62 \%)$ \\
\hline
\end{tabular}


Neha Yadav et.al Histomorphological Study of Leprosy with Clinical Correlation in Kumaon Region

\begin{tabular}{|c|c|c|c|c|c|c|c|c|}
\hline Dermal changes & & IL (21) & TT (5) & BT (8) & BL (11) & LL (16) & BB (1) & Total $(n=62)$ \\
\hline \multirow[t]{2}{*}{ 1.Grenz zone } & Present & $3(14.28 \%)$ & $0(0 \%)$ & $\begin{array}{c}3(37.50 \\
\%)\end{array}$ & $\begin{array}{c}8(72.70 \\
\%)\end{array}$ & $\begin{array}{c}14(87.50 \\
\%)\end{array}$ & $1(100 \%)$ & $29(45.16 \%)$ \\
\hline & Narrow & $0(0 \%)$ & $0(0 \%)$ & $4(50 \%)$ & $\begin{array}{c}2(18.18 \\
\%)\end{array}$ & $1(6.30 \%)$ & $0(0 \%)$ & $7(12.90 \%)$ \\
\hline \multirow[t]{2}{*}{$\begin{array}{l}\text { 2.Epithelioid cells } \\
\text { granuloma }\end{array}$} & Well formed & $0(0 \%)$ & $5(100 \%)$ & $\begin{array}{c}3(37.50 \\
\%)\end{array}$ & $0(0 \%)$ & $0(0 \%)$ & $1(100 \%)$ & $9(14.51 \%)$ \\
\hline & ill formed & $0(0 \%)$ & $0(0 \%)$ & $\begin{array}{c}5(62.50 \\
\%) \\
\end{array}$ & $\begin{array}{c}1(9.09 \% \\
) \\
\end{array}$ & $3(18.75 \%)$ & $0(0 \%)$ & $9(14.51 \%)$ \\
\hline \multirow[t]{3}{*}{ 3.Lymphocytes } & Scant & $\begin{array}{l}18(85.71 \\
\%)\end{array}$ & $0(0 \%)$ & $0(0 \%)$ & $\begin{array}{c}4(36.36 \\
\%)\end{array}$ & $8(50 \%)$ & $0(0 \%)$ & $30(48.38 \%)$ \\
\hline & Moderate & $3(14.28 \%)$ & $4(80 \%)$ & $\begin{array}{c}7(87.50 \\
\%)\end{array}$ & $\begin{array}{c}5(45.45 \\
\%)\end{array}$ & $7(43.75 \%)$ & $1(100 \%)$ & $27(43.54 \%)$ \\
\hline & Numerous & $0(0 \%)$ & $1(20 \%)$ & $\begin{array}{c}1(12.5 \% \\
)\end{array}$ & $\begin{array}{c}2(18.18 \\
\%)\end{array}$ & $1(6.25 \%)$ & $0(0 \%)$ & $5(8.06 \%)$ \\
\hline \multirow{3}{*}{$\begin{array}{l}\text { 4.Lymphocytes } \\
\text { around }\end{array}$} & $* \mathbf{P V}$ & $\begin{array}{l}14(66.66 \\
\%)\end{array}$ & $1(20 \%)$ & $\begin{array}{c}3(37.50 \\
\%)\end{array}$ & $\begin{array}{c}3(27.27 \\
\%)\end{array}$ & $\begin{array}{c}13(81.25 \\
\%)\end{array}$ & $1(100 \%)$ & $35(56.45 \%)$ \\
\hline & $\dagger \mathbf{P A}$ & $5(23.80 \%)$ & $\begin{array}{c}3(60.00 \\
\%)\end{array}$ & $\begin{array}{c}4(50.00 \\
\%)\end{array}$ & $\begin{array}{c}4(36.36 \\
\%)\end{array}$ & $2(12.50 \%)$ & $0(0 \%)$ & $18(29.03 \%)$ \\
\hline & $\$ \mathbf{P N}$ & $2(9.52 \%)$ & $1(20 \%)$ & $\begin{array}{c}1(12.50 \\
\%)\end{array}$ & $\begin{array}{c}4(36.36 \\
\%)\end{array}$ & $1(6.25 \%)$ & $0(0 \%)$ & $9(14.51 \%)$ \\
\hline \multirow[t]{2}{*}{ 5.Giant cells } & Present & $0(0 \%)$ & $4(80 \%)$ & $0(0 \%)$ & $0(0 \%)$ & $0(0 \%)$ & $0(0 \%)$ & $4(6.45 \%)$ \\
\hline & Absent & $21(100 \%)$ & $1(20 \%)$ & $8(100 \%)$ & $\begin{array}{c}11(100 \\
\%)\end{array}$ & $16(100 \%)$ & $1(100 \%)$ & $58(93.54 \%)$ \\
\hline \multirow{2}{*}{$\begin{array}{l}\text { 6.Foamy } \\
\text { macrophages/ } \\
\text { histiocytes }\end{array}$} & $\dagger \mathbf{P A} / \$ \mathbf{P N}$ & $0(0 \%)$ & $2(40 \%)$ & $4(50 \%)$ & $\begin{array}{c}5(45.45 \\
\%)\end{array}$ & $3(18.75 \%)$ & $0(0 \%)$ & $17(27.41 \%)$ \\
\hline & $\begin{array}{l}\text { Granulomato } \\
\text { us aggregates }\end{array}$ & $0(0 \%)$ & $0(0 \%)$ & $0(0 \%)$ & $\begin{array}{c}6(54.54 \\
\%)\end{array}$ & $\begin{array}{c}13(81.25 \\
\%)\end{array}$ & $0(0 \%)$ & $16(25.80 \%)$ \\
\hline \multirow[t]{3}{*}{$\begin{array}{l}\text { 7.Location of } \\
\text { granuloma }\end{array}$} & $\S \mathbf{P D}$ & $0(0 \%)$ & $1(20 \%)$ & $\begin{array}{c}1(12.50 \\
\%)\end{array}$ & $\begin{array}{c}1(9.09 \% \\
) \\
\end{array}$ & $0(0 \%)$ & $0(0 \%)$ & $3(4.83 \%)$ \\
\hline & \$PD \&//RD & $0(0 \%)$ & $4(80 \%)$ & $\begin{array}{c}5(62.50 \\
\%) \\
\end{array}$ & $\begin{array}{c}6(54.54 \\
\%) \\
\end{array}$ & $\begin{array}{c}12(56.25 \\
\%) \\
\end{array}$ & $1(100 \%)$ & $28(45.16 \%)$ \\
\hline & $/ / \mathbf{R D}$ & $0(0 \%)$ & $0(0 \%)$ & $2(25 \%)$ & $0(0 \%)$ & $1(6.25 \%)$ & $0(0 \%)$ & $3(4.83 \%)$ \\
\hline \multirow[t]{3}{*}{ 8.Dermal nerve } & Normal & $0(0 \%)$ & $2(40 \%)$ & $0(0 \%)$ & $\begin{array}{c}2(18.18 \\
\%)\end{array}$ & $0(0 \%)$ & $1(100 \%)$ & $5(8.06 \%)$ \\
\hline & Eroded & $0(0 \%)$ & $0(0 \%)$ & $\begin{array}{c}1(12.50 \\
\%)\end{array}$ & $\begin{array}{c}1(9.09 \% \\
) \\
\end{array}$ & $1(6.25 \%)$ & $0(0 \%)$ & $3(4.83 \%)$ \\
\hline & Thickened & $0(0 \%)$ & $0(0 \%)$ & $\begin{array}{c}1(12.50 \\
\%)\end{array}$ & $\begin{array}{c}1(9.09 \% \\
) \\
\end{array}$ & $1(6.25 \%)$ & $0(0 \%)$ & $3(4.83 \%)$ \\
\hline
\end{tabular}

Table 1(b): Dermal changes*PV-Perivascular, $\uparrow$ PA- Periappendageal, $\$$ PN- Perineural, $§$ PD- Papillary dermis, // RDReticular dermis

The Clinico-histopathological correlation was highest in IL (7 cases; $100 \%$ ) and TT ( 2 cases; $100 \%$ ) followed by BL (6 cases; $60 \%$ ) and least in BT (7 cases; 36.84\%) leprosy. Among the 19 clinically diagnosed cases of BT, 8 cases $(42.1 \%)$ were of IL, 7 cases $(36.84 \%)$ were of BT, and 2 cases $(10.52 \%)$ were of LL and 1 case $(5.26 \%)$ was of TT and BL each.

Of the total 10 clinically diagnosed cases of BL, 6 cases $(60 \%)$ cases were of BL, 2 cases $(20 \%)$ were of IL and 1 case $(10 \%)$ was of TT and BB each. Overall clinical and Of the 24 clinically diagnosed cases of LL, 14 cases $(58.33 \%)$ 
Neha Yadav et.al Histomorphological Study of Leprosy with Clinical Correlation in Kumaon Region

were of LL, 4 cases (16.66\%) were of IL and BL each and 1 case $(4.16 \%)$ was of TT and BT each. histopathological correlation was seen in 36 cases $(58.06 \%)$

[Table 2].

Table 2: Clinico-histopathological correlation of leprosy:

\begin{tabular}{|c|c|c|c|c|c|c|c|c|c|c|}
\hline \multicolumn{9}{|c|}{ Histopathological groups } & \multirow[b]{2}{*}{ Kappa value } & \multirow[b]{2}{*}{ P value } \\
\hline \multirow{6}{*}{$\begin{array}{l}\text { Clinical } \\
\text { groups }\end{array}$} & & IL (21) & $\begin{array}{c}\text { TT( } \\
\text { 5) }\end{array}$ & $\begin{array}{c}\text { BT( } \\
\text { 8) }\end{array}$ & $\begin{array}{l}\text { BL(11 } \\
\text { ) }\end{array}$ & $\begin{array}{l}\mathbf{L L}( \\
6)\end{array}$ & $\begin{array}{l}\mathbf{B B}( \\
\text { 1) }\end{array}$ & $\%$ of agreement & & \\
\hline & IL (7) & 7 & 0 & 0 & 0 & 0 & 0 & $7 / 7 * 100=100 \%$ & 0.398 & 0.001 \\
\hline & TT (2) & 0 & 2 & 0 & 0 & 0 & 0 & $2 / 2 * 100=100 \%$ & 0.551 & 0.001 \\
\hline & BT (19) & 8 & 1 & 7 & 1 & 2 & 0 & $7 / 19 * 100=36.8 \%$ & 0.412 & 0.001 \\
\hline & BL (10) & 2 & 1 & 0 & 6 & 0 & 1 & $6 / 10 * 100=60 \%$ & 0.484 & 0.001 \\
\hline & LL (24) & 4 & 1 & 1 & 4 & 14 & 0 & $14 / 24 * 100=58.3 \%$ & 0.565 & 0.001 \\
\hline
\end{tabular}

* In our study no BB case was diagnosed clinically, however 1 case was diagnosed on histopathology

$\dagger$ Overall clinico-pathological correlation was seen in $36(58.06 \%)$ cases.

On doing agreement analysis (Kappa test) between the clinical and histological classification of different subtypes of leprosy cases, there was fair agreement in making diagnosis of IL, BT, borderline lepromatous BL [Table2].

On examination of histological sections after Wade-Fite staining it was observed that out of total 62 cases, majority of the (32 cases; $51.61 \%$ ) cases were paucibacillary [PB] type and 30 cases $(48.38 \%)$ were multibacillary [MB type] [Table 3].

No acid fast bacilli could be demonstrated in any of the case of indeterminate leprosy. Amongst cases of TT and BT, 1 out of 5 cases $(20 \%)$, and 1 out of 8 cases $(12.5 \%)$ showed presence of acid fast bacilli with BI of $1+$ and $2+$ respectively.

Table 3: correlation of histopathological classification of leprosy with Bacterial index on histological sections:

\begin{tabular}{|c|c|c|c|c|c|c|c|c|}
\hline \multirow{10}{*}{ 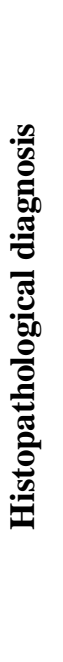 } & \multicolumn{8}{|c|}{ Bacteriological index } \\
\hline & \multirow{2}{*}{$\begin{array}{l}\text { Histopathologic } \\
\text { al Type }\end{array}$} & \multirow{2}{*}{$\begin{array}{c}\text { Paucibacillary } \\
0 \\
\end{array}$} & \multicolumn{6}{|c|}{ Multibacillary } \\
\hline & & & $1+$ & $2+$ & $3+$ & $4+$ & $5+$ & $6+$ \\
\hline & IL (21) & $21(100 \%)$ & $0(0 \%)$ & $0(0 \%)$ & $0(0 \%)$ & $0(0 \%)$ & $0(0 \%)$ & $0(0 \%)$ \\
\hline & TT(5) & $4(80 \%)$ & $1(20 \%)$ & $0(0 \%)$ & $0(0 \%)$ & $0(0 \%)$ & $0(0 \%)$ & $0(0 \%)$ \\
\hline & $\mathbf{B T}(\mathbf{8})$ & $7(87.50 \%)$ & $0(0 \%)$ & $\begin{array}{c}1(12.50 \\
\%)\end{array}$ & $0(0 \%)$ & $0(0 \%)$ & $0(0 \%)$ & $0(0 \%)$ \\
\hline & BL(11) & $0(0 \%)$ & $0(0 \%)$ & $0(0 \%)$ & $0(0 \%)$ & $\begin{array}{c}7(63.60 \\
\%)\end{array}$ & $\begin{array}{c}4(36.30 \\
\%)\end{array}$ & $0(0 \%)$ \\
\hline & $\mathbf{L L}(16)$ & $0(0 \%)$ & $0(0 \%)$ & $0(0 \%)$ & $0(0 \%)$ & $\begin{array}{c}1(6.25 \% \\
)\end{array}$ & $8(50 \%)$ & $\begin{array}{c}7(43.75 \\
\%)\end{array}$ \\
\hline & $\mathbf{B B}(\mathbf{1})$ & $0(0 \%)$ & $0(0 \%)$ & $0(0 \%)$ & $1(100 \%)$ & $0(0 \%)$ & $0(0 \%)$ & $0(0 \%)$ \\
\hline & Total $(n=62)$ & $32(51.61 \%)$ & & & $30(4$ & $39 \%)$ & & \\
\hline
\end{tabular}

*Slit skin smears were made in 52 cases.

Among BL, 7 cases $(63.6 \%)$ showed BI of $4+$ and 4 cases $(36.3 \%)$ showed BI of $5+.1$ case $(1.61 \%)$ of BB was diagnosed on histopathology with BI of 3+[Figure 6]. Amongst 16 cases of
LL, $8(50 \%)$ cases showed acid fast bacilli with bacterial index of $5+, 7$ cases $(43.75 \%)$ with BI of $6+[$ Figure 7] and 1 case $(6.25 \%) \quad$ with $\mathrm{BI}$ of $4+$ 


\section{Neha Yadav et.al Histomorphological Study of Leprosy with Clinical Correlation in Kumaon Region}

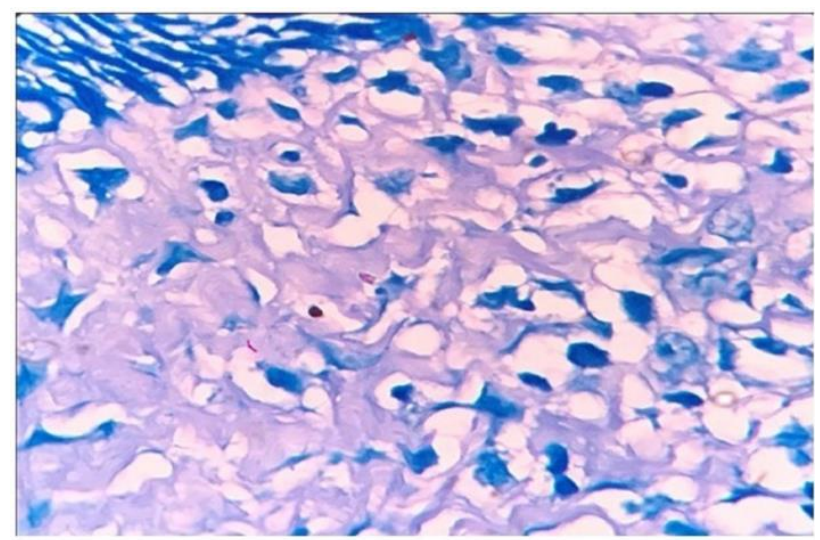

Figure 6: Bacterial index of $3+$ in Boderline Bordeline leprosy (Wade-Fite stain; X1000)

\section{Discussion:}

The R-J classification is used worldwide because it is comprehensible and gives a good clinico-histological correlation along with the advantage of objectivity. However the results of different studies done by different authors showed non uniformity and diversities between the clinical and histopathological features. The present study uses R-J classification clinically and histopathologically to classify leprosy. Indeterminate cases of leprosy were also included for analysis.

The present study included 62 clinically suspected Leprosy patients over a period of 2 years from September 2016 to August 2018. Majority of cases (16 cases; 25.80\%) belonged to the age group of 11-20 yrs. Male were affected more frequently than female. The clinical profile of the patients showed that the majority of the patients belonged to the lepromatous leprosy group ( 24 cases; $38.70 \%$ ) as also noted by Khamankar ST et al., ${ }^{[3]}$ while the study conducted by Banushree CS et al. ${ }^{[4]}$ showed majority of patients in borderline tuberculoid group. The increased number of lepromatous leprosy in our study indicates immunologically depressed population or delay in approaching health services for treatment due to our region being a hilly area.

Histopathologically, the most commonly encountered type of leprosy was IL (21 cases; 33.90\%), followed by LL (16 cases; $25.80 \%)$ and the least common type was the BB (1 cases; $1.61 \%$ ). Similar observations were made by Singh J et al. ${ }^{[5]}$ and Arunagirinathan $\mathrm{M}$ et al., ${ }^{[6]}$ while BT was the most common type in the study done by Badhan $\mathrm{R}$ et al. ${ }^{[7]}$ and Rizvi A A et al. ${ }^{[8]}$ The high percentage of IL noted histopathologically in our study could have been due to immunological differences in host responses, duration of the lesion, nature and depth of the biopsy, quality of the sections and number of acid fast stained sections examined. Selection of the site of biopsy also plays an important role since clinically different lesion biopsied from same patient can show different type of histopathology. This can be resolved by appropriate selection of site and adequate depth of the biopsy to be taken. Our study showed highest clinicohistopathological correlation in IL and TT cases. Similar observation was made by Hazarika D. et al. ${ }^{[9]}$ and Kumar A

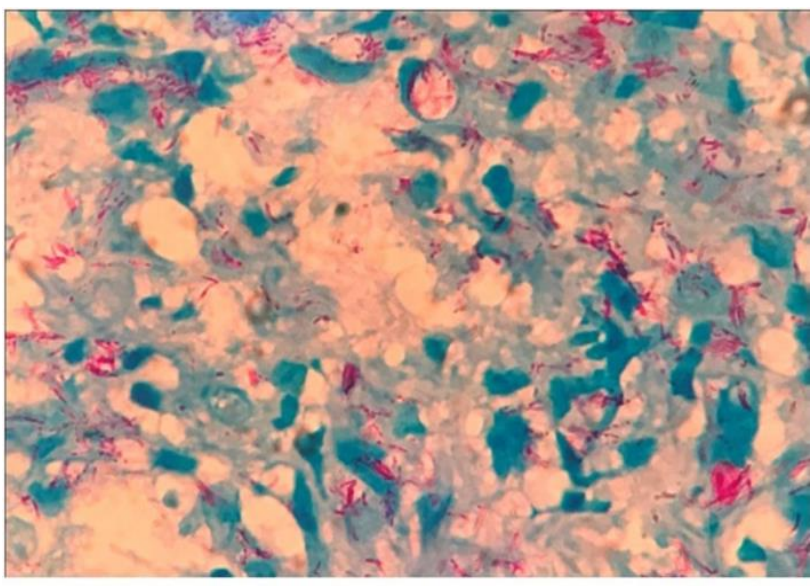

Figure 7: Bacterial index of 6+ in lepromatous leprosy (Wade-Fite stain; X1000).

et al. ${ }^{[10]}$ while study done by Banushree CS et al. ${ }^{[4]}$ showed highest clinico-histopathological correlation in LL. The variation may be due to different criteria used to select the cases in different studies. The present study showed an overall clinico-histopathological concordance in 36 cases $(58.06 \%)$

The discordance between clinical and histopathological diagnosis was noticed in 26 cases (41.93\%) because the clinical examination gives recognition only to gross appearance of the lesions caused by the underlying pathology, whereas the histopathological features in leprosy are well defined and precise and indicates the accurate response of the tissue and also takes into account the bacillary index in biopsy sections. The inter-observer variation in assessment of clinical lesions and interpretation of biopsy by the inexperienced person can lead to overlap between different types of leprosy. The disparity in clinicohistopathological correlation can be resolved by adopting uniform criteria for clinical and histopathological evaluation of leprosy and proper assessment of immunological status of the patient by new diagnostic equipments.

In the present study, majority of the patients were of PB type (32 cases; $51.61 \%$ ) and the rest were of MB type (30 cases; $48.38 \%$ ) on tissue sections. Similar observations were made by Badhan $\mathrm{R}$ et al. ${ }^{[7]}$ while study done by Giridhar et al. ${ }^{11}$ showed majority of patients were of MB type (55 cases; $56.13 \%$ ). The bacterial index on SSS was calculated in 52 cases, out of which 17 cases $(32.69 \%)$ were positive for acid fast bacilli [Table 4].Similar observation was made by Shresta et al. ${ }^{[12]}$ in which bacterial index on SSS was positive in 12 cases $(25 \%)$. This indicates that the evaluation of bacterial index on biopsy is better than SSS for assessing the bacterial load as SSS only reflects density of bacilli in a focus while biopsy takes into account size of foci, bacterial density and also accessibility of bacilli present in deep dermis.

Epidermis was unremarkable in majority (58cases; $93.54 \%$ ) of the biopsies while it was either eroded ( 2 cases; $3.22 \%$ ) or 


\section{Neha Yadav et.al Histomorphological Study of Leprosy with Clinical Correlation in Kumaon Region}

atrophic (2 cases; $3.22 \%$ ) in rest of the cases. Similar observations were made by Shivamurthy $\mathrm{V}$ et al. ${ }^{[13]}$ which showed unremarkable epidermis in most of the biopsies (78.50\%). The erosion and atrophy of epidermis is caused by granuloma located in papillary dermis as majority of cases in our study belonged to IL in which no granuloma is seen, so epidermis was unremarkable.

In the present study grenz zone was the commonest feature observed in most of the biopsies of LL (14 cases; $87.50 \%$ ) and BL (8 cases; $72.70 \%$ ) while it was absent in all cases of TT. Similar observations were made by Shivamurthy V et al ${ }^{[}$ ${ }^{13]}$ and Suri SK et al. ${ }^{[14]}$ Absence of grenz zone in TT and BT in majority of the cases can be due to the fact that activation of $\mathrm{T}$ helper1(Th1) cells induces delayed type of hypersensitivity and formation of granuloma.

In our study, all the biopsies of TT (5 cases; $8.10 \%$ ) showed epithelioid granulomas $(100 \%)$ while moderate periappendageal lymphocytes were seen in 3 cases $(60 \%)$ and giant cells were seen in 4 cases (80\%) [Figure 4].

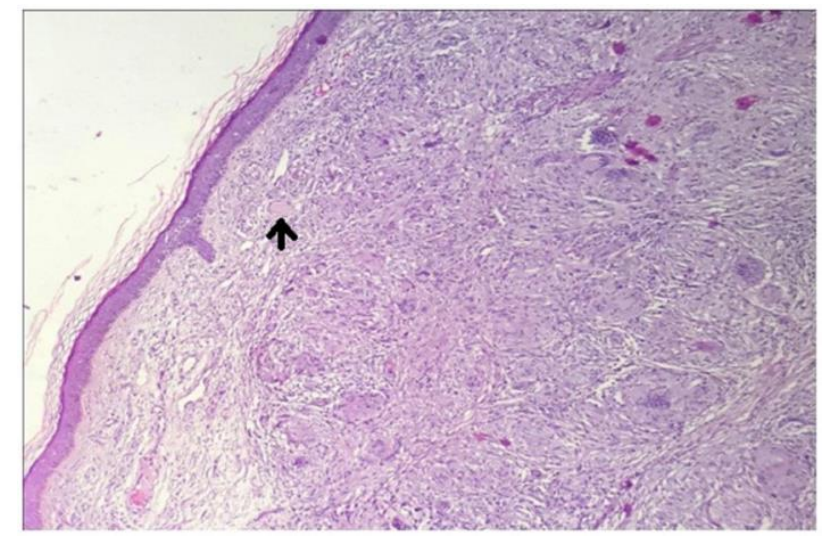

Figure 4: Tuberculoid leprosy: multiple well formed epitheloid granulomas with langhans giant cells (arrow) and moderate lymphocytes (H\&E; X100).

Similar observations were made by Banushree C S et al. ${ }^{[4]}$ in which the epithelioid cell granulomas were seen in all the cases of TT $(100 \%)$, giant cell were seen in 13 cases $(61.90 \%)$ and periappendageal lymphocytes in 14 cases $(66.66 \%)$. More number of lymphocyte in TT leprosy indicates the good immunological response of the host.

Out of 62 biopsies, 8 cases $(12.90 \%)$ were of BT and majority of them (7 cases; $87.5 \%)$ showed moderate lymphocytes which were mainly located around the appendages (4 cases; 50\%). Well formed epithelioid granulomas were seen in only 3 cases $(37.5 \%)$ while giant cells were not seen in any case. These finding are quite similar to study done by Suri SK et al. ${ }^{[14]}$ in which epithelioid cell granulomas was seen in 9 cases(47.4\%) and periappendageal lymphocytes in majority of cases (8 cases; $42.1 \%$ ).

In our study, BB leprosy constituted the least common type of leprosy (1case; $1.60 \%$ ) and it showed presence of grenz zone and epithelioid granuloma. Similar observation was made by Suri S K et al. ${ }^{[14]}$ in which 1 case of $\mathrm{BB}$ was diagnosed on histopathology with presence of grenz zone.
The most common finding in biopsies of IL (21 cases; $33.90 \%$ ) was the presence of scant lymphocytic aggregates around the perivascular location (14 cases; 66.66\%) [Figure 3].

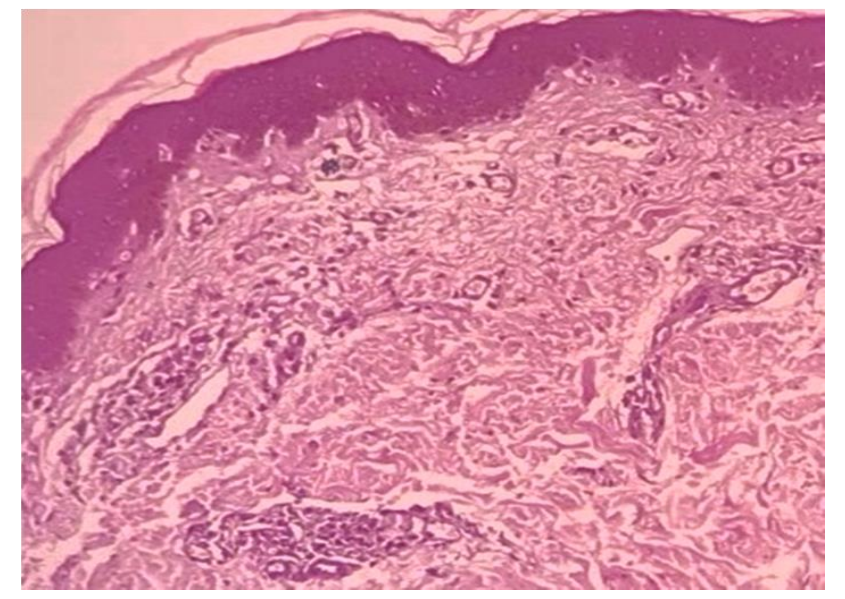

Figure 3: Indeterminate leprosy: scant perivascular lymphocytic infiltrate (H\&E; X100).

Similar observation was made by Suri S K et al. ${ }^{[14]}$ in which perivascular lymphocytes were seen in 8 cases (100\%).

All the 11(17.70\%) biopsies of BL leprosy showed foamy macrophages/ histiocytes (100\%) with formation of macrophage granulomas in 6 cases $(54.54 \%)$ only. Lymphocytes were moderate in most ( 5 cases; $45.45 \%$ ) of the cases and were present mainly in periadnexal or perineural location (4 cases; 36.36\%).Similar observations were made by Banushree CS et al. ${ }^{[4]}$ in which lymphocytes were seen in periappandageal or perineural location in all 10 cases $(100 \%)$.

Of the $16(25.80 \%)$ biopsies of $\mathbf{L L}$ all demonstrated presence of foamy macrophages / histiocytes with formation of macrophage granulomas in $13(81.25 \%)$ cases [Figure 5].

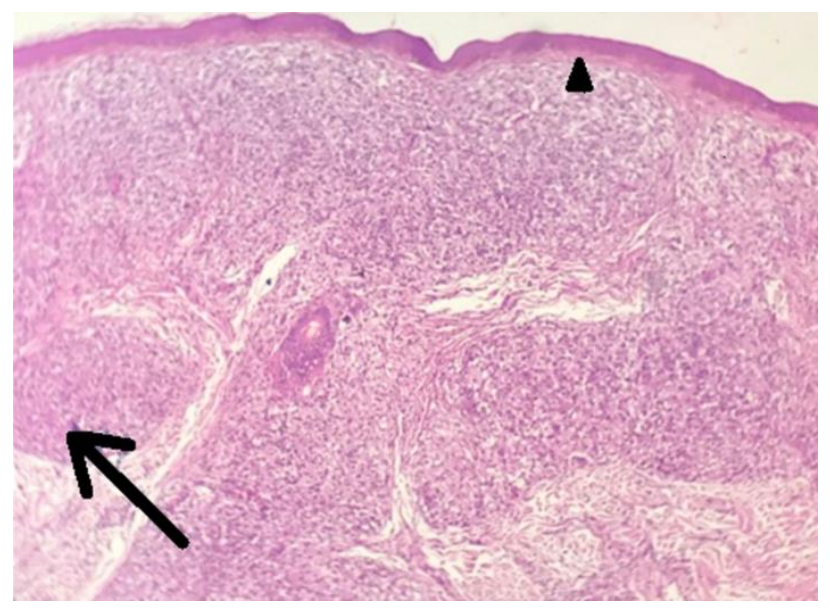

Figure 5: Lepromatous leprosy: granulomas composed of foamy macrophages/histiocytes (arrow) and presence of clear zone (arrow head) (H\&E; X100)

Scant lymphocytes were seen in majority of cases (8 cases; $50 \%)$. Similar observations were made by Ridley DS. ${ }^{[2]}$ 
In LL, T-helper2 (Th2) are activated which inhibits cell mediated immunity so there is an inability to develop significant $\mathrm{T}$ cell mediated delayed hypersensitivity reaction to the leprae bacilli. ${ }^{[15]}$ The net result is inability to control the bacteria and accumulation of the bacilli within foamy macrophages, leading to foamy degenerative changes. Presence of scant lymphocytes in the cases of LL is also due to decreased immunological response of the host.

In the present study granuloma of either epithelioid cell or foamy macrophages was seen in 32 cases (53.33\%). Somatosensory and autonomic neuropathic manifestations of the disease depend on the location of the granuloma.

Granuloma is unlikely to cause epidermal changes and hypopigmented skin lesions when it is situated in the mid dermis or in the deep dermis or if it is small granuloma. Atrophy of the epidermis and development of hypopigmented lesions occurs when the granuloma reaches the superficial dermis.

Small sample size, unknown immune status of the patients and possibility of non representative biopsy were the main limitations of this study. Better diagnostic techniques (molecular studies, PCR, serological tests) were not adopted in skin biopsies, showing more clinico-pathological discrepancies. In histologically proven cases of indeterminate leprosy and borderline leprosy, repeat serial biopsy from the same lesion was not taken. As this was a tertiary care centre- hospital based study, the results may not reflect the real status of the leprosy and real status in the field setting.

\section{Conclusion}

Our study showed that the most common type of leprosy was IL in kumaon region. Our study has also demonstrated overlapping histological features of different types of leprosy in some cases, highlighting that B.I. should be calculated in all the biopsies for better classification of the cases. Some early/ indeterminate/ borderline cases of leprosy may bemuse clinically as they may lack cardinal signs and symptoms of leprosy. In such cases, clinicopathological correlation could improve diagnostic yield and treatment.

\section{References}

1. [National Leprosy Eradication Programme- Annual report for the year 2015-2016. Nirman Bhavan, New Delhi: Central Leprosy Division, Directorate General of Health Services, Ministry of Health and family welfare (GOI); 2016. Available from: http://nlep.nic.in/pdf/revised\%20annuals\%20report \%2031st\%20 March\%202015-16.pdf

2. Ridley DS, Jopling WH. Classification of leprosy according to immunity: A five group system. Int J Lep Other Mycobac Dis 1996;34:255-73.
3. Khamankar ST, Wagha S, Dawande P. Recent trend in leprosy: Histopathological study aspect in a tertiary care hospital. Indian J Basic Appl Med Res 2016;5:481-6.

4. Banushree CS, Bhat RV, Udayashankar C. Clinicopathological correlation of Hanshen's disease:a retrospective study of skin biopsies. Indian J pathol oncol 2016;3:491-5.

5. Singh J, Rai MK. Clinicopathological correlation of leprosy in Jharkhand. IOSR J Dent Med Sci 2016;15:50-8.

6. Arunagirinathan M, Muniswamy V, Jeevirathinam S. Clinical and Histopathological Correlation in Hansen's Disease. Ann Pathol Lab Med 2017; 4:A454-9.

7. Badhan R, Kundal RK, Raj RT, Bahl RK, Bal MS. A clinicopathological correlation study of leprosy in a tertiary care teaching institute in Northwest Punjab, India. Am J Med Sci Med 2014;2:99-108.

8. Rizvi AA, Sharma YK, Dash K, Tyagi N, Yadava R, Sadana D. An epidemiological and clinicohistopathological study of leprosy in semi-urban area under Pimpri Chinchwad Municipal Corporation in Pune district of Maharashtra. Med J DY Patil Univ. 2015;8:609-13.

9. Hazarika D, Pawar MK, Dowerah E. A Prospective Study of Clinico-Histopathological Correlation among Leprosy Patients Attending a Tertiary Referral Centre in Assam, in This Post Elimination Era. Int J Health Sci Res 2017;7:148-53.

10. Kumar A, Negi SR, Vaishnav K. A study of Clinico-histopathological correlation of leprosy in a tertiary care hospital in western district of Rajasthan. J Res Med Den Sci 2014;2:43-8.

11. Giridhar M, Arora G, Lajpal K, Chahal KS. Clinicohistopathological concordance in LeprosyA Clinical, Histopathological and Bacteriological study of 100 cases. Indian J Lepr 2012;84:217-5.

12. Shrestha A, Chauhan S, Mathur, M. Clinicohistopathological correlation of leprosy. JPN. [Internet]. 2017 Mar [cited 2019 Mar 18];7(1):[1095-102.]. Available from: http://www.nepjol.info/ index.php/JPN/article/view/16946

13. Shivamurthy V, Gurubasavaraj H, Sastry SP, Kumar P. Histomorphological study of leprosy. Afr J Med Health Science 2013;12:68-73.

14. Suri SK, Iyer RR, Patel DU, Bandil S, Baxi S. Histopathology and clinico-histopathological correlation in Hansen's disease. J Res Med Den Sci. 2014;2:37-44.

15. McAdam AJ, Milner DA, Sharpe AH. Infectious Diseases. In: Kumar V, editor. Robbins and Cotran Pathologic basis of disease, South Asia ed. Phildelphia: Reed Elsvier Inc; 2015. p. 341-402 